\title{
三次元き裂進展自動解析システムの構築*
}

（第 2 報，き裂進展解析システムとき裂進用有限要素法モデル生成）

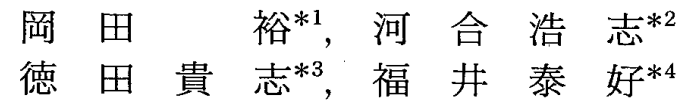

\section{Development of Automated Crack Propagation Analysis System}

(2nd Report, the Crack Propagation Analysis System and Finite Element Model Generation for the Crack Propagation)

\author{
Hiroshi OKADA*5, Hiroshi KAWAI, \\ Takashi TOKUDA and Yasuyoshi FUKUI \\ ${ }^{* 5}$ Faculty of Science and Technology, Department of Mechanical Engineering, Tokyo University of Science, \\ 2641 Yamazaki, Noda-shi, Chiba, 278-8510 Japan
}

\begin{abstract}
The authors have been developing a fully automated three-dimensional crack propagation analysis system. Although three-dimensional finite element analyses have become a common tool in the industries to perform design analyses, there still exist many difficulties in performing threedimensional crack propagation analyses. That is because, although fully automatic mesh generation techniques are available for tetrahedral finite elements, hexahedral elements are commonly used in three-dimensional crack analyses. Furthermore, the analysis models tend to be large in their scales. The key components of present analysis system are the mesh generation software and virtual crack closure-integral method (VCCM) for the second-order tetrahedral finite element. VCCM is an energetic method to compute the stress intensity factors. In this paper, methodologies in automatic mesh generation for crack propagation analysis are described in detail and some numerical examples are presented.
\end{abstract}

Key Words : Finite Element Method, Crack Propagation, Stress Intensity Factors, Computational Mechanics

\section{1. 粕言}

エネルギ一機器や種々の社会的インフラストラクチ ヤ一の経年化とそれらの構造健全性の保証は大変重要 な課題である（例えば，文献 $\left.{ }^{(1)}\right)$. それらの代表的な 構造損傷は疲労や応力腐食割れによるき裂の発生と進 展（拡大）である（例えば，文献(1)(2)）。き裂損傷に対 する構造健全性評価を適切に行うため, 有限要素法に よる応力解析とそれに基づくき裂パラメータ（応力拡

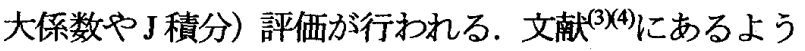
に，複雑な形状を有する部位にき裂損傷が発生する.

一方，近年のコンピュータハードウエアの急速な進 歩により，解析実行可能な解析モデル規模が年々大型 化している. パーソナルコンピュータでも数十〜百万

\footnotetext{
* 原稿受付 2010 年 7 月 30 日.

*1 正員, 東京理科大学理工学部機械工学科(宓 278-8510 野田 市山崎 2641).

*2 東京大学大学院工学系研究科システム創成学専攻(画 113 8656 東京都文京区本郷 7-3-1).

*3 鹿児島大学大学院理工学研究科機械工学専攻 ( $\$ 890-0065$ 鹿児島市郡元 1-21-40).

*4 正員, 鹿児島大学大学院理工学研究科機械工学專攻.

E-mail : hokada@rs.noda.tus.ac.jp
}

自由度レベルの三次元固体力学解析を容易に実行する ことが可能である. その際, 有限要素法モデル生成は $\mathrm{CAD}$ で生成されたソリッドモデルデータからメッシ ユ生成ソフトウェアで行うことが一般的である.

有限要素法解析モデルの自動生成手法は原理的に四 面体有限要素だけに対応することができ（谷口ら(5)な ど），三次元固体力学解析で四面体有限要素の使用が 一般的になりつつある. しかしながら，つ最近でも 実用的な三次元破壊力学解析の多く（例えば，革新的 実用原子力技術開発費補助事業報告書 ${ }^{(6)(7)}$ ) 泣六面体有 限要素によって実行されてきた，その理由として，破 壊力学解析に従事寸る技術者や研究者の多くは六面体 有限要素が四面体有限要素に比べて精度に優れると考 えているであろうこと，破壊力学パラメータ計算手法 のプログラム実装が六面体有限要素に対して提案され

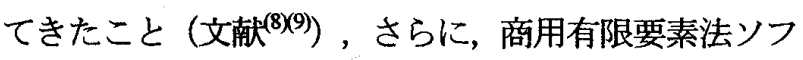
トウエア（例えば，資料 ${ }^{(10)}$ ) が破壊力学解析で六面体 有限要素の使用を要求することが考えられる.そこで, 筆者らは，四面体 2 次要素用の仮想き裂閉口積分法

（Virtual Crack Closure-Integral Method; VCCM）を提案 し，三次元き裂問題へ適用してきた ${ }^{(11)(12)}$. さらに，節 
点群をベースとする, 三次元き裂問題に対する有限要 素法解析モデル生成手法を提案し，き裂が二次元的曲 面を持つ場合でも適用可能なことを示した ${ }^{(13)}$.また, 河合ら ${ }^{(14)}$ では, き裂進展問題に対する有限要素法解析. モデル生成に関する基本的な考え方が示された. しか しながら，河合ら ${ }^{(14)}$ は裂の成長とともにき裂前縁形 状の近似精度やき裂前縁近傍に配置された有限要素の アスペクト比が悪化するという問題があった。

筆者らは, き裂進展解析システムの開発を進めてき た. その中で, き裂進展に伴う有限要素法解析モデル の更新がその中心的役割を担う。そのため, 河合ら の手法を改良し, VCCM 計算結果に基づくき裂形状の 更新手法や, き裂進展後の有限要素のアスペクト比や き裂前縁形状の近似精度の悪化が少ない有限要素法解 析モデルの生成手法の開発を進めてきた. 本報では, き裂進展解析システムの概要と有限要素法解析モデル 生成に関する詳細について議論し, さらに, 例題とし て丸棒と平板の表面き裂進展問題解析を示す. 本報で 報告する解析システムにより, 完全自動で疲労や応力 腐食割れ問題に対するき裂進展解析の実施が可能にな る.

\section{2. き翌進展解析システム}

本研究で構築してきたき裂進展解析システムの構成 を図 1 に示す。前報 (13)で報告したき裂解析システムに き裂進展機能を追加したものである. 図 1 は解析シス テムが有するプログラム/モジュールと入出カデータ セットの関係を表したものである. 進展き裂に対する 有限要素法解析モデル生成は, 大まかに分けると, き 裂進展による新しい節点群の生成, それらの前き裂進 展ステップで用いたき裂節点群への合体，不要となる 節点の削除, デロー二法を使用した四面体有限要素に
よる有限法解析モデルの生成のステップからなる.さ らに, 本き裂進展解析システムは, 境界条件の指定, 有限要素法解析, 解析結果に基づき仮想き裂閉口積分 法（VCCM） ${ }^{(11)(12)}$ による応力拡大係数の計算と, き裂 進展速度と進展方向の予測を行うプログラムから構成 される.

本解析システムでは, 解析モデルの大規模化に対応 するために有限要素法解析を並列有限要素法解析プロ

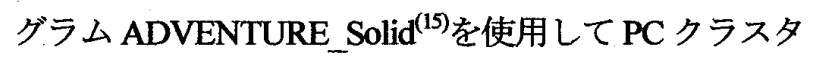
一上で行う. その他の応力拡大係数の算出や有限要素 法解析モデルの生成は Linux PC 上で害行し, 有限要素 法解析の入カファイルと解析結果の出力ファイルの送 受信を, LANを介して行う. 図 1 に示すように, 各プ ログラムはそれぞれの入出力データによって連結され， き裂進展解析を自動実行する.

次章では，き裂進展に係る有限要素法解析モデルの 生成手法の詳細について述べる.

\section{3. き裂進展に伴う有限要素法解析モデルの生成}

本章では, き裂進展に伴う有限要素法解析モデルの

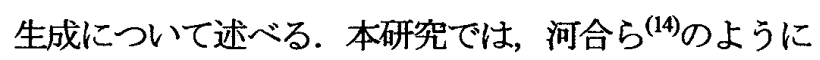
前のステップまでのき裂面に関する幾何学的情報を保 持しつつ, 毎き裂進展ステップごとに有限要素法解析 モデルを新たに生成する，ところが，有限要素法解析 の結果から VCCM で計算する応力拡大係数には様々 な理由で数值誤差が含まれる. その誤差は, 岡田ら ${ }^{(1)}$ で示したように, 応力桩大係数の分布を表したグラフ 上で細かい振動として現れる. そのような応力拡大係 数から予測したき裂進展速度とキンク角にも䛊差が含 まれることが懸念される. そのため, 最小二乗法をき 裂進展量や進展後き裂形状の平滑化に使用する.

以下に，き裂節点群に基づくき裂メッシュの生成の

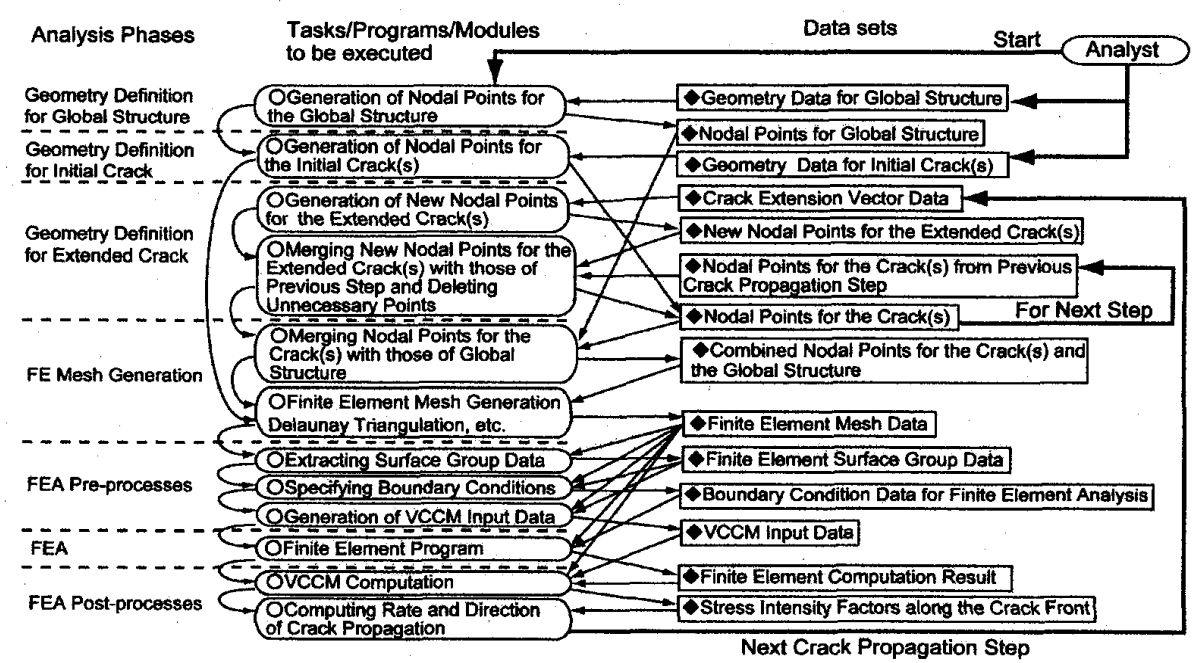

Fig. 1 Software design and data flow of proposed crack propagation analysis system 
概要，き裂進展方向と速度の予測，平滑化を伴うき裂 進展量や進展後き裂形状の決定法等の詳細を示す.

3-1 き裂節点群に基づくき裂メッシュ生成の概要 前報(13)で報告したように，き裂を，き裂を表すき裂節 点群によって表す。その際き裂前縁は節点 $\left(\left(x^{I_{\text {Front }}}, y^{I_{\text {Frout }}}, z^{I_{\text {Fromt }}}\right), I_{\text {Front }}=1,2,3, \cdots, N_{\text {Front }}\right)$ を慗 ぐ線分によって定義する，き裂前縁節点間の距離はほ ぼ一定となるよう与えることとし，ここではその距離 を $\Delta_{\text {Front }}$ と書く.また, き裂面の形状も節点群で表す. これらが，き裂の幾何形状情報である.

それらをき裂法線方向に重わ合わせてき裂節点群 を生成し，構造全体を表す全体節点群と合体した後， デローニ法(5)によるメッシュ生成を行う．さらにき裂 前縁で有限要素の細分割老行う。き裂面内の有限要素 各面の配置とき裂面上の節点群を図 2 に模式的に表す.

\section{2 応力拡大係数の計算とき裂進展速度と進展方}

向の予澌 応力拡大係数は有限要素法解析モデル のき裂前縁に配置された各要素に対して算出される (11)(22).三次元き裂問題では，図3に示すようにき裂キ ンクとねじれ角をき裂前縁各点で決定する必要がある. 例えば, Richard ら ${ }^{(1)}$ ではキンク角 $(\varphi)$ やねじれ角 ( $\psi$ ）の予測式を次のように与えている.

$$
\begin{gathered}
\varphi=-\left[140^{\circ}\left(\left|\Delta K_{I I}\right| / \Delta \bar{K}\right)-70^{\circ}\left(\left|\Delta K_{I I}\right| / \Delta \bar{K}\right)^{2}\right] \\
\times \operatorname{sgn}\left(\Delta K_{I I} / \Delta K_{I}\right) \\
\psi=-\left[78^{\circ}\left(\left|\Delta K_{I I I}\right| / \Delta \bar{K}\right)-33^{\circ}\left(\Delta K_{I I I} \mid / \Delta \bar{K}\right)^{2}\right] \\
\times \operatorname{sgn}\left(\Delta K_{I I I} / \Delta K_{I}\right)
\end{gathered}
$$

ただし, $\Delta \bar{K}=\Delta K_{I}+\left|\Delta K_{I I}\right|+\left|\Delta K_{I I I}\right|$ である.

さらに，等価応力拡大係数振幅 $\left(\Delta K_{e q}\right)$ から Paris

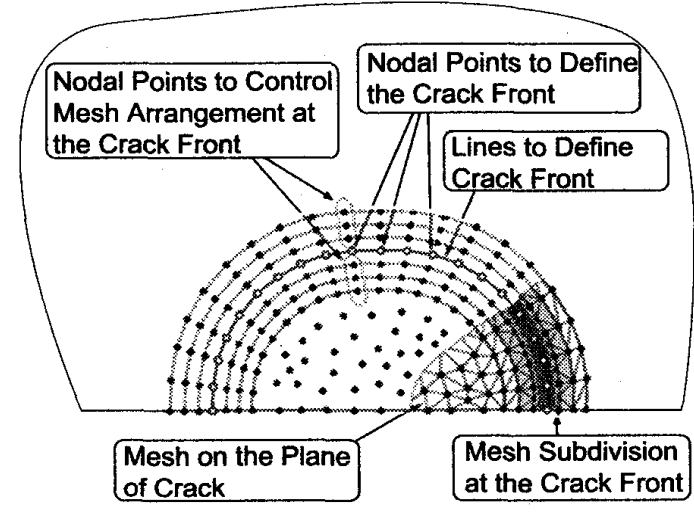

Fig. 2 Arrangements of nodal points to define the crack front geometry and finite elements on the plane of the crack

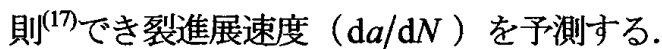

$$
\begin{aligned}
\Delta K_{e q}= & \frac{\Delta K_{I}}{2} \\
& +\frac{1}{2} \sqrt{\Delta K_{I}^{2}+4\left(\alpha_{1} \Delta K_{I I}\right)^{2}+4\left(\alpha_{2} \Delta K_{I I I}\right)^{2}} \\
& \left(\alpha_{1}=1.155, \alpha_{2}=1\right) \\
\frac{\mathrm{d} a}{\mathrm{~d} N} & =C\left(\Delta K_{e q}\right)^{n}
\end{aligned}
$$

式 (4) 中の $C, n$ は材料定数である. 例えば, 発電 用原子力設備規格持規格 ${ }^{(18)}$ によれば，それらは室温中 のステンレス鋼（例えば，SUS316）に対して $C=2.05 \times 10^{-12}$ と $n=3.3$ が典型的な值として知られ ている.ただし，き裂のねじれ角を考虑すると，き裂 前縁形状がファクトリールーフ状き裂(19)のように不 連続になることを考慮しなければならず，現在の三次 元き裂解析の枠組みで表現することができない，その ため, 本研究ではき裂のキンク角 $(\varphi)$ だけを考慮す る. その他，疲労き裂進展に関するき裂のキンク角の 予測や等価応力搪大係数の計算方法注種々提案されて いる(例えば，文献 $\left.{ }^{(20)}\right)$.

以上の議論から，き裂前でのき裂進展速度をべクト ル表記することができ，その成分と絶対値を $\left(\mathrm{d} a_{x} / \mathrm{d} N\right.$ ， $\left.\mathrm{d} a_{\mathrm{y}} / \mathrm{d} N, \mathrm{~d} a_{\mathrm{z}} / \mathrm{d} N\right)$ と $\mathrm{d} a / \mathrm{d} N$ で表す.

3-3 き裂進展豆の決定 1 回のき裂進展ステッ プでの最大き裂進展長さを, $3 \cdot 1$ 節で定義した要素細 分化前のき裂前縁節点間の距離 $\left(\Delta_{\text {Front }}\right)$ から与える.

VCCM 計算の精度を確保するため, き裂前縁近傍で き裂面が滑らかな領域を十分大きく設定する必要があ る. そのため, き裂前縁近傍の有限要素寸法に対して 数倍のき裂進展長さを与える. 本研究では 1 き裂進展 ステップあたりの最大き裂進展長さ $\Delta a_{\mathrm{Max}}$ を $\Delta_{\mathrm{Front}}$ の3 倍とした $\left(\Delta a_{\mathrm{Max}}=3 \Delta_{\mathrm{Front}}\right)$ ．これより，き裂前 縁各点のき裂進展速度の最大值からこのステップの繰 返し荷重サイクル数 $\left(N_{K} ; K\right.$ はき裂進展ステップ

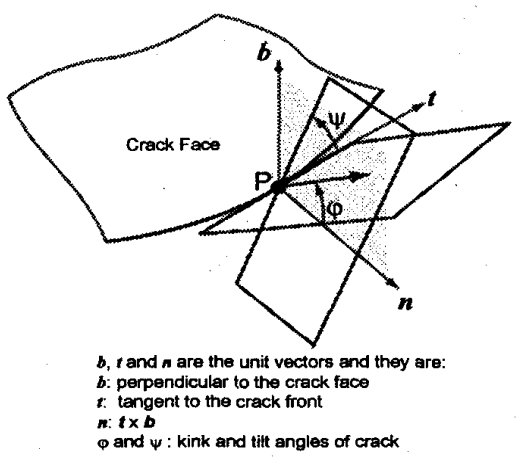

Fig. 3 Kink and tilt angles of crack 
数）を定める。き裂前縁で $\mathrm{d} a / \mathrm{d} N$ の最大值を $(\mathrm{d} a / \mathrm{d} N)_{\text {Max. }}$ とすれば, $N_{K}$ を次式で定める.

$$
N_{K}=\frac{\Delta a_{\text {Max. }}}{(\mathrm{d} a / \mathrm{d} N)_{\mathrm{Max}}}
$$

以上より，き裂前縁各点のき裂進展量をベクトル表示 することができ，以下の議論でき裂進展ベクトルとよ ぶ.

$$
\left(\Delta a_{x}, \Delta a_{y}, \Delta a_{z}\right)=N_{K}\left(\frac{\mathrm{d} a_{x}}{\mathrm{~d} N}, \frac{\mathrm{d} a_{y}}{\mathrm{~d} N}, \frac{\mathrm{d} a_{z}}{\mathrm{~d} N}\right)
$$

3 -4 き裂進展ベクトルの平滑化 はじめに, 式

（6）によって有限要素法解析モデルのき裂前縁位置 （節点またはき裂前縁セグメント）で算出されたき裂 進展ベクトルを，き裂前縁形状を定義する各節点に与

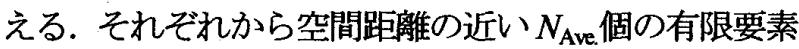
法解析モデルのき裂前縁位置で算出されたき裂進展量 ベクトルの平均值を用いる.

次に，それらの值から最小二乗近似を行い，き裂前 縁形状を定義する節点のき裂進展量に対して平滑化を 行う。そのために，き裂前縁と物体の自由表面の交差 点を原点とするき裂前縁の距離座標 $s$ を定義し，使用 する. き裂前縁形状を定義する各節点について， $s$ 座 標値の近い $N_{\mathrm{LSQ}}$ 個の節点からき裂進展べクトルを最 小二乗法近似により $s$ の二次式で表し，その二次式か ら各節点毎にき裂進展ベクトルを再計算する。このよ うにして平滑化されたき裂進展べクトルを（ $\Delta a_{x}^{I_{\text {Front }}}$ ，

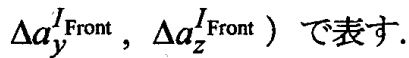

以上の概要を図 4 に模式的に示す.

3.5 谁展後き裂前绿形状の生成 前節のき裂進 展ベクトルを用い，図 4 や 5 に示すようにき裂前粶座

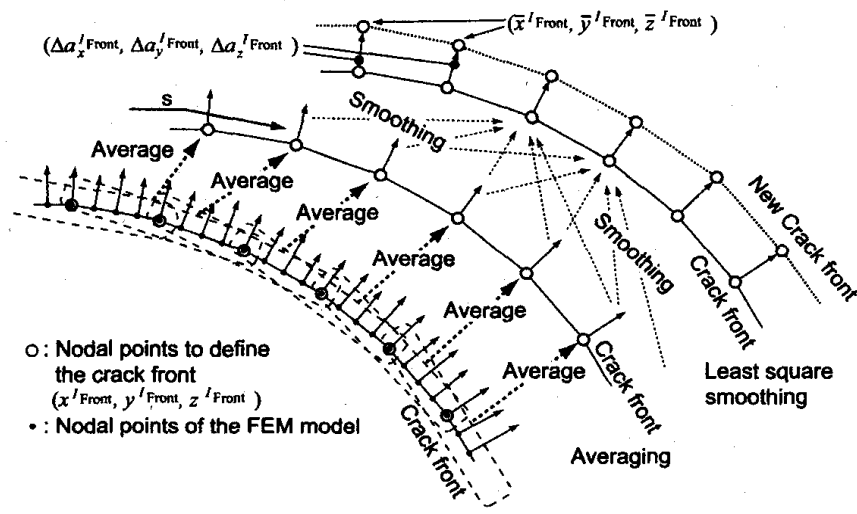

Fig. 4 Smoothing the crack propagation vector data based on the stress intensity factors that are evaluated by VCCM
標を更新し，( $\left.\bar{x}^{I_{\text {Froot }}}, \bar{y}^{I_{\text {Front }}} ， \bar{z}^{I_{\text {Front }}}\right)$ と表す。

ところが，き裂前縁形状を定義する各節点の座標值 をそれらのき裂進展量に基づき更新し続けると，例え ば板材の表面き裂のような場合，節点どうしの距離が 大きく離れてしまう。.その結果, き裂前縁で生成され る有限要素のアスペクト比の悪化が懸念される，そこ で，節点間の距離 $\Delta_{\text {Front }}$ をほぼ一定に保つため，以下 のようにき裂前縁の節点数とそれらの座標を再定義す る.

はじめに，更新された節点座標を利用し，き裂前縁 の距離座標（ $\hat{s}$ ) を再定義する. 次に, き裂前縁形状 を定義する節点の距離座標値を，それらの間の間隔が 距離座標 $(\hat{s})$ 上で一定値（ $\Delta_{\text {Front }}$ ) となるよう与え る. 更新されたき裂前縁形状を定義する節点の総数を $\hat{N}_{\text {Front }}$ ，それぞれの $\hat{s}$ 座標値を $\hat{s}_{J_{\mathrm{Front}}} \quad\left(J_{\mathrm{Front}}=1,2,3\right.$, $\left.\cdots, \hat{N}_{\text {Front }}\right)$ とする. 新しい節点 $J_{\text {Front }}$ の座標値 $\left(\hat{x}^{J_{\text {Froot }}}\right.$,

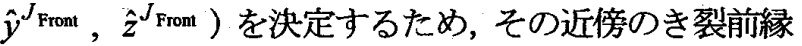
形状を， $\hat{s}_{J_{\mathrm{Front}}}$ の近い $N_{\mathrm{LSQ}}$ 個の節点座標值から最小二 乗法により $\hat{s} に$ 関する二次関数による近似式で表す。 その近似式を用いて新しい節点座標値 $\left(\hat{x}^{J_{\text {Front }}}, \hat{y}^{J_{\text {Front }}}\right.$,

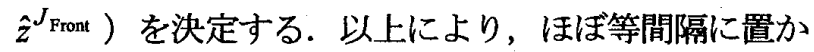
れた節点で裂前縁形状が定義される（図 5）。

3.6 き秝進展による新しい節点群の生成 前節 までで定義した新しいき裂前縁形状に従い，き裂進展 による新しいき裂節点群を生成する. はじめに, 図 5 に示した進展後き裂前縁形状を定義する各節点からき 裂進展方向に沿って節点を数点配置する. 例えば本論 文における例題では，き裂前縁近傍でき裂面の滑らか な部分を十分大きく設定することができるよう最大き 裂進展量を $3 \Delta_{\text {Front }}$ と設定した. 節点を各き裂前縁から き裂側に 2 点, リガメント側に 3 点等間隔に配置した （図6参照）。さらに，各節点をその法線べクトル方 向にき裂の雨側に，数層ずつコピーした節点群を追加 する. 本報の例題では 3 層とし，それらの間の距離

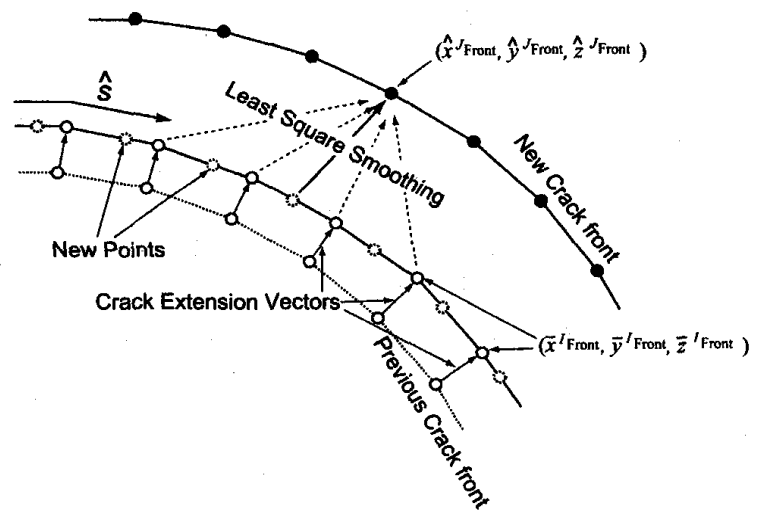

Fig. 5 Generation of new crack front geometry based on the crack extension vectors and least square method 
は1 1.5 $\Delta_{\text {Front }}$ としている.

以上のプロセスから，半棈円き裂の愓合壮図7(a) のよう にリングを半分にしたような節点群配置を得る.このよう

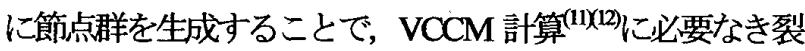
前粶節点配置を得ることができる.

\section{3 -7 き裂進展による新しい節点群の既存のき裂節} 点群への合体 図7 (a) のようなき裂進展節点群を 図 7 (b) のような既存のき裂節点群に合体する. 既存 のき裂モデル節点群と新規に生成したき裂進展節点群 の占める領域に重なりが生ずる領域では, 既存モデル 節点群中の節点を消去する．既存モデル節点之新規節 点の間の距離が, $\Delta_{\text {Front }}$ の 0.6 1.5 倍末満の場合, 既 存節点を消去する. 図 7 (c) に合体後の節点群を示す.

3-8 有限要素法解析モデルの生成 前報(13) と同 様，き裂を表す節点群を全体モデル（図 8 (a)) に合体 し，デロー二法(5)によって全体モデルを生成する，そ の結果, 図 $8(\mathrm{~b})$ のような有限要素法解析モデルを得る.

\section{4. 数值解析例}

本章では, Newman and Raju ${ }^{(21)}$ による表面き裂の進展 問題と提案のき裂進展プログラムによる解析結果の比 較を行い，さらに，丸棒のねじり問題におけるき裂進 展解析例を示す．前者では，提案のき裂進展解析プロ グラムによる解析結果が信頼性を有すること, 後者で はき裂が配置された物体表面の曲率やき裂のキンクが あってもき裂進展解析が可能なことを示す。

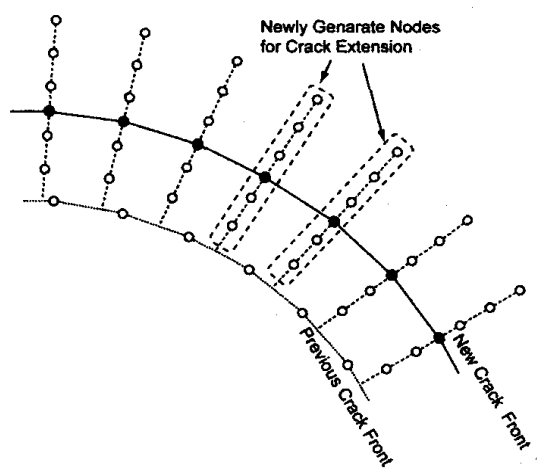

Fig. 6 Newly generated nodal points on the crack face and its extended plane for crack propagation
なお，本報の解析では，き裂進展に係るパラメータ $\Delta_{\text {Front }}$ を初期き裂の表面幅の $1 / 20$ 程度に設定し, $N_{\text {Ave }}$ は 40， $N_{\mathrm{LSQ}}$ は 10 とした. これらのパラメータの設定 によっては，必要以上のスムーシングによりき裂形状 を変えてしまう恐れがある，今回の解析ではき裂がほ ぼ半棈円形状になることが予想され，矛盾の無い結果 が得られている.よって，それらパラメータの設定值 が最適ではなくても適切であったと考えられる.

4-1引張を受ける平板のき裂進展解析 図9に 初期き裂形状を含む解析モデル概要を表す．初期き裂 のアスペクト比 (き裂の染さ $\mathrm{b}$ と表面寸法 $\mathrm{a}$ の比, b/a は $1.0,0.8$ と 0.65 の 3 通り，板厚一き裂表面寸法 $\mathrm{a}$ の 比 $\mathrm{a} / \mathrm{t}$ を 0.1 とした.き裂進展速度を予測する式(4) 中の定数 $\mathrm{n}$ は Newman and Raju ${ }^{(21)}$ と同じ值，4 とした. ただし，文献 ${ }^{(21)}$ 中では物体内部と表面部で平面ひずみ と平面応力状態の違いを表現するため，定数 C を表 面部で最深部の $0.9^{n}$ としているが，本報の解析では き裂前縁全ての点で同じ值を用いた。 文献 ${ }^{(21)}$ 中では, き裂進展量と繰返し荷重サイクル数の関係が示されて いないのでき裂形状に関する比較だけを行った.

図 10 に，初期き裂のアスペクト比 $\mathrm{b} / \mathrm{a}$ が 1.0 の場 合の有限要素法モデルと進展後のき裂形状を示す．図 10 からは，ほぼ半だ円形となり，き裂が成長すること がわかる．ただし，形状を表すためなので，図 10 (a) と (b) で図中に示すようにそれらのスケールは異なる. なお，初期状態での総要素数と節点数は 45 万と 55 万 程度であった．き裂成長とともにそれらは増加し，き 裂梁さが板厚の $80 \%$ 弱となる最終ステップででは 80 万と 115 万程度になった。 き裂進展に伴うき裂のアス ペクト比 $\mathrm{b} / \mathrm{a}$ と，き裂媣さと板厚の比 $\mathrm{b} / \mathrm{t}$ の変化を図 11 に示す. 図 11 はき裂進展に伴うき裂形状の変化を 表す. 図 11 に本解析の結果と Newman and Raju ${ }^{(21)}$ 。の 比較も示す. Newman and Raju ${ }^{(21)}$ と本解析の結果を比 較すると，本解析の方がき裂のアスペクト比 $\mathrm{b} / \mathrm{a}$ が 0.1 0.15 程度小さな值を保ちながらき裂が進展してい く.なお, 図 11 では, Newman and Raju ${ }^{(21)}$ 中の図から 值を読み取り作図を行った. Newman and Raju ${ }^{(21)}$ では

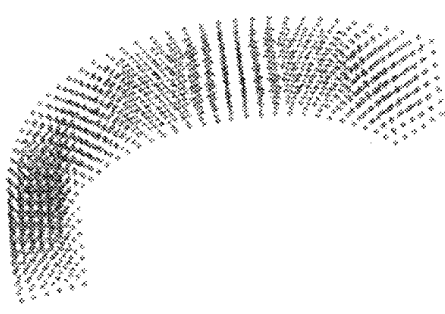

(a) Extended part

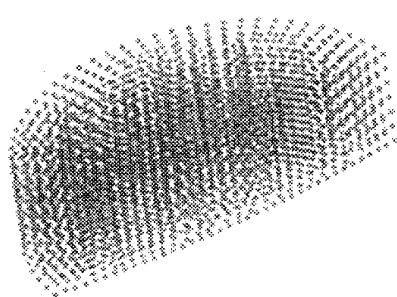

(b) Before the extended part is merged

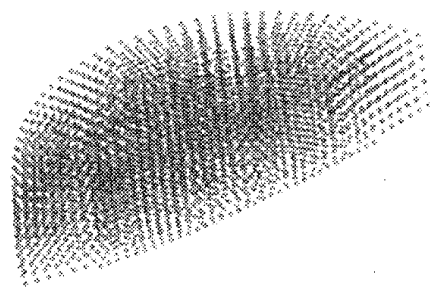

(c) After the extended part is merged

Fig. 7 Groups of nodal points for the extended part of the crack and those before and after the extend part is merged 

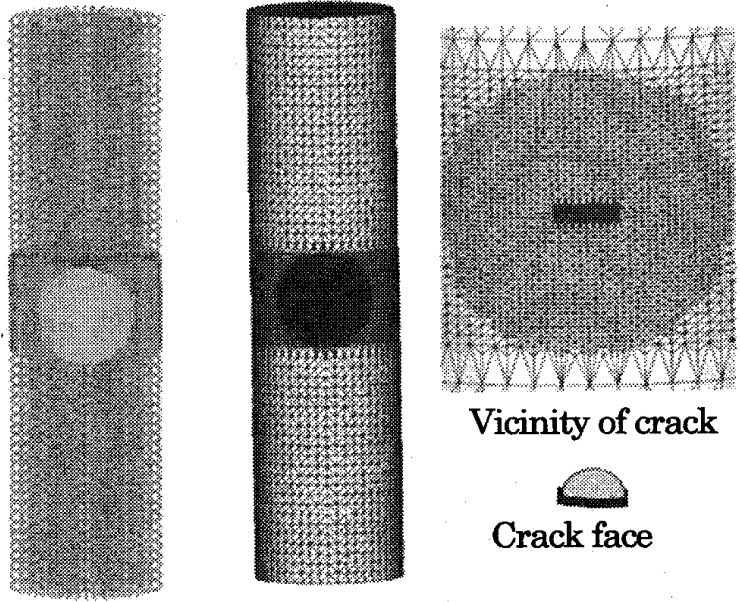

Vicinity of crack

Crack face

(a) Points for the

(b) A finite element model global model with a crack

Fig. 8 A group of nodal points for the global model and a finite element model with a crack

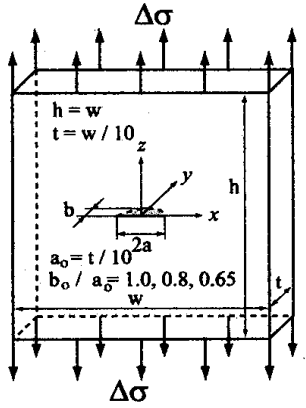

(a) Analysis model geometry

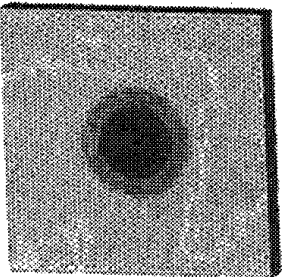

(b) Finite element mesh
Fig. 9 Surface crack propagation problem to compare with the analyses of Raju and Newman ${ }^{(21)}$ き裂最染部と表面部で異なるき裂進展則を仮定してい るが，本解析では同じとしたのでき裂表面部の進展速 度が速くなるためと思われる. 今後, 種々の問題へ応 用に際してき裂前縁全域で同一のき裂進展則を使用す べきか検討すべきであろう。

\section{4・2 实りや引张を受ける丸柍のき裂進展解析}

図 12 に据りや引張を受ける丸棒のき裂問題を表す.初 期き裂のアスペクト比（a/b) は 1.0，軸方向に対して 垂直な場合と角度 $\pi / 8$ 傾いた場合の解析を行う。初 期き裂が丸棒の断面に対して傾きを持つ場合，軸方向 荷重のみを仮定した．初期き裂が丸棒の垂直断面内の 場合, 軸荷重と㨝りトルクを同時に与えた. それぞれ， き裂がキンクして進展することを想定した問題である. き裂の無い丸棒中と表面に軸応力とせん断応力振幅 $\Delta \sigma=\Delta \tau=140 \mathrm{MPa}$ を発生する軸荷重と据りトルク の振幅を $\Delta \bar{F}$ と $\Delta \bar{T}$ とし，それらを一定割合ずつ同 時に負荷する. 表 1 に本例題の負荷状態を示す：図 13 に典型的な解析モデルを示す.図 13 は傾いた初期き裂

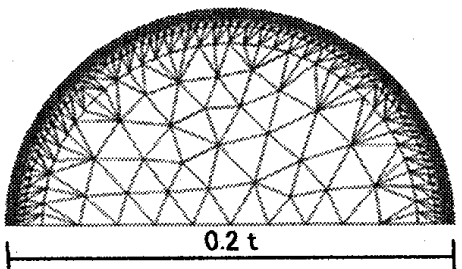

(a) Initial crack

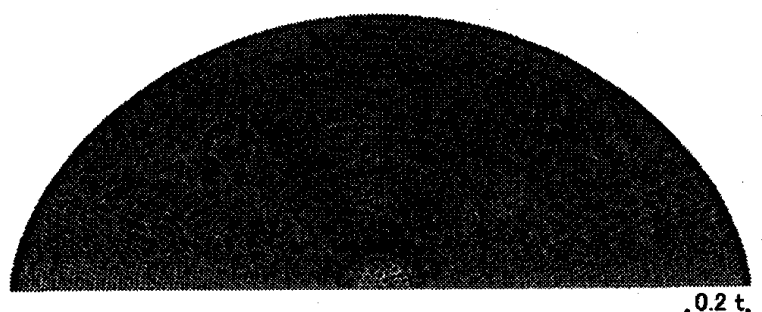

(b) After crack propagation: $a / t=1.014$

$0.2 t$ Fig. 10 Evolution of crack shape after its growth (initial aspect ratio $b / a=1$ )

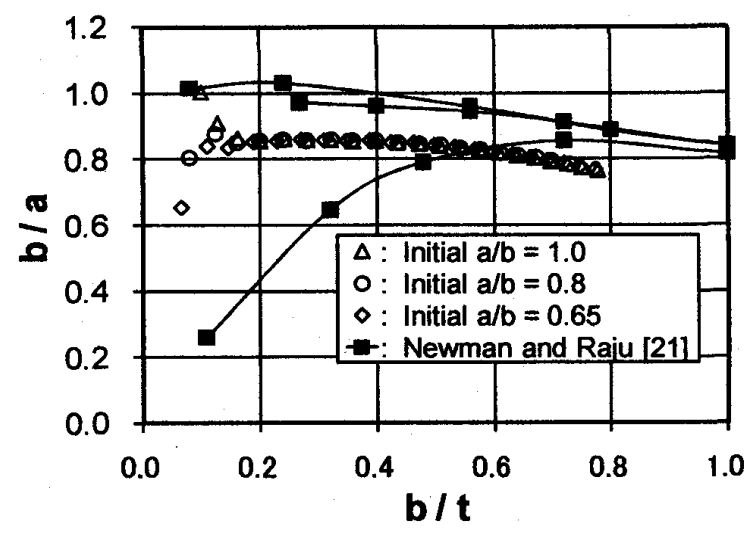

Fig. 11 Evolution of crack aspect ratio and depth

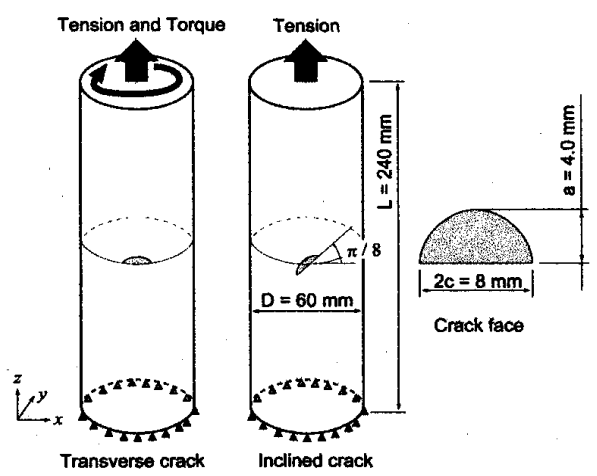

Fig. 12 Problems of circular bar subject to tension and/or torsion

Table 1 Summary of the loading conditions for the problems of cylindrical bar

\begin{tabular}{|c|c|c|}
\hline Analysis Case & Axial force & Torque \\
\hline $\begin{array}{c}\text { Inclined crack } \\
\text { (angle: } \pi / 8 \text { ) }\end{array}$ & $\Delta \bar{F}$ & 0 \\
\hline Normal crack & $0.8 \times \Delta \bar{F}$ & $0.2 \times \Delta \bar{T}$ \\
\hline
\end{tabular}

$\Delta \bar{F}$ produces the normal stress of $\Delta \sigma=140 \mathrm{MPa}$.

$\Delta \bar{T}$ produces the torsional stress of $\Delta \tau=140 \mathrm{MPa}$. 


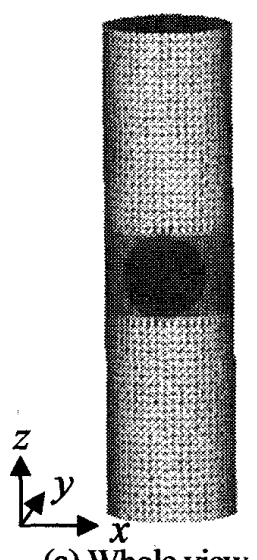

(a) Whole view

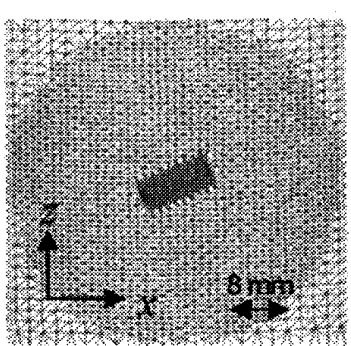

(b) Close view of crack

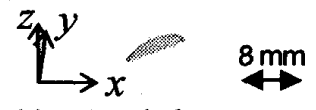

(c) Crack face

Fig. 13 A typical finite element mesh for the problem of circular bar (initial state for the inclined crack case) の場合である. き裂が丸棒に垂直な場合やき裂進展後 でも，き裂の近傍以外の要素分割は同じである.

Paris 則の定数はステンレス鋼を仮定し， $C=2.05 \times 10^{-12}$ と $n=3.3$ を使用した。

図 14 と図 15 にそれぞれの場合におけるき裂進展の 様相を示す，き裂はそれらの初期状態からキンクし，

例えば，初期状態で傾いたき裂が軸荷重を受ける場合 は，丸棒に対して重直な力向にき裂が進展する（図 14）。 すなわち，モードI 応力拡大係数が支配的となるよう な向きにき裂が進展する. 軸荷重と据りトルクが同時 に作用する場合は，き裂が傾いた向きに進展していく （図 15）.なお，図中に参考として，本解析システム で計算した繰返し荷重サイクル数を示す．き裂の大き さの拡大とともに，1荷重サイクルあたりのき裂進展 量が大きくなるので，1 き裂進展解析ステップあたり の荷重サイクルが少なくなる. 他の解析や実験結果と 定量的な比較をすることは困難であるが，定性的には 妥当な解析結果を得たと考えられる.

絰節点数と要素数は，初期状態で両問題ともに約 70 万 と 51 万，15 ステップのき裂進展後で約 106 万と 76 万であ る. き裂進展とともに，き裂に関係する節点が増吋するた め, 総節点と要素数も堌加する.

\section{5. 結}

本報では，開発したき裂進展システムの詳細な内容 と，例題解析結果を示した. 四面体有限要素法解析の

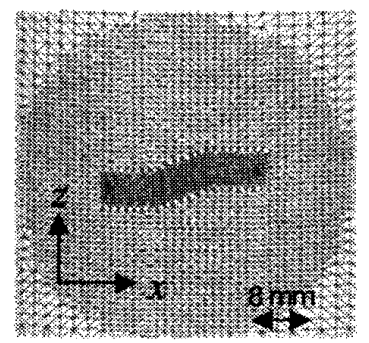

Surface of the bar

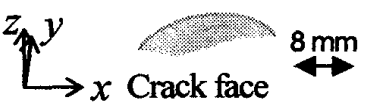

(a) After 5 steps (451267 cycles)

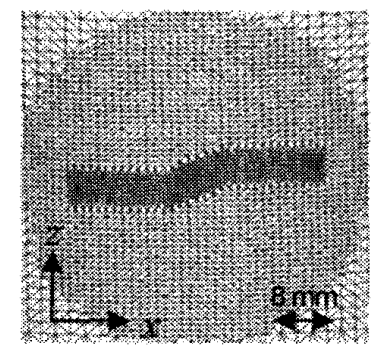

Surface of the bar

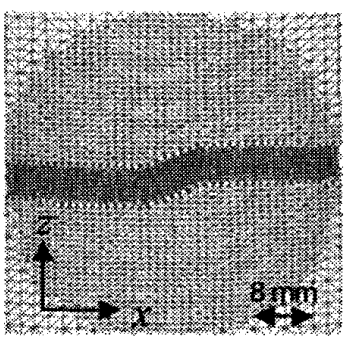

Surface of the bar

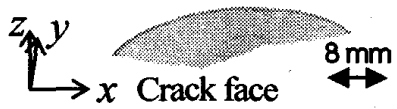

(b) After 10 steps ( 609557 cycles)

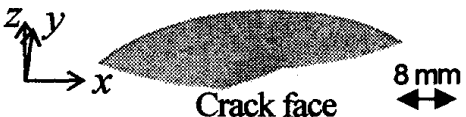

(c) After 15 steps ( 667164 cycles)

Fig. 14 Evolution of crack face during the fatigue crack growth for the initially inclined crack problem

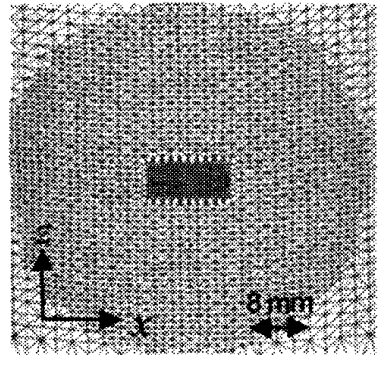

Surface of the bar

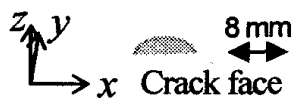

(a) Initial flaw

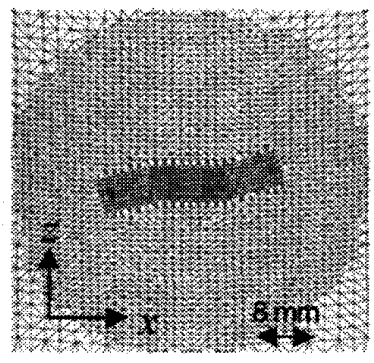

Surface of the bar

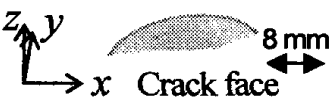

(b) After 5 steps

(758471 cycles)

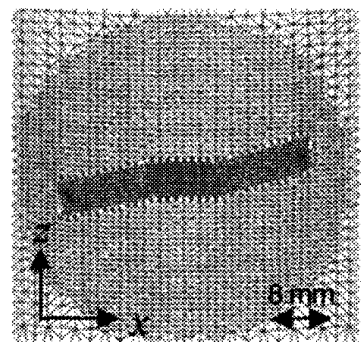

Surface of the bar

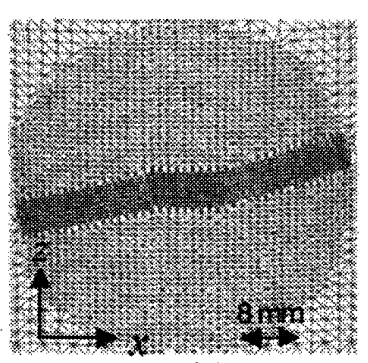

Surface of the bar

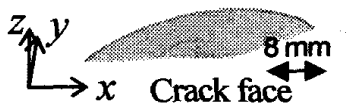

(c) After 10 steps

(1023293 cycles)

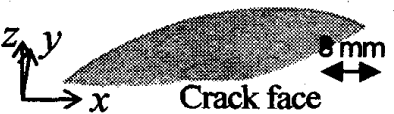

(d) After 15 steps

(1126330 cycles)

Fig. 15 Evolution of crack face during the fatigue crack growth for the initially normal crack problem 
結果から得られる応力拡大係数には様々理由で誤差が 含まれる(11)，そのため，本報で報告したようなき裂進 展量や方向, そして, 進展後き裂前縁形状の平滑化処 理が必要である.

今後は, より複雑なモデル形状に対応するため, よ り一般的な曲面形状への対応できるよう手法を改良す る予定である.また, き裂のキンク角が大きい場合は, 本報の解析で使用したデローニ法によるき裂メッシュ 生成が困難な場合がある. そこで, 今後, 拘束デロー 二法(22)をき裂モデル生成に応用し，よりロバストなき 裂モデル生成手法を構筑する予定である. 問題中に複 数のき裂や残留応力を有する場合の解析も本論文の手 法の拡張により解析が可能になるので今後の課題とし たい.

最後に，本論文中で紹介した平板中のモード I き裂 進展解析は東京理科大学理工学研究科機械工学専攻修 士課程, 金子修平君に実施して頂いたことに感謝する。

\section{文献}

(1) Atluri, S. N., Sampath, S. G., Tong, P. ed., Structural Integrity of Aging Airplanes, (1991), p. 37 ,Springer-Verlag.

(2) Yagawa, G. ed., Structural Engineering Handbook, (2004), p. 157, Maruzen.

(3) Spievak, L. E, Wawrzynek, P. A., Ingraffea, A. R., Lewicki, D. G., Simulating Fatigue Crack Growth in Spiral Bevel Gears, Eng. Fract. Mech., Vol. 68 (2001), 53-76.

(4) Morita, A, Kagawa, H., Sugawara, M., Kondo, Y., Kubo, S., Evaluation of Corrosion Fatigue Crack Propagation Life at Low-Pressure Turbine Groove, Eng. Fract. Mech., Vol. 73 (2006), 1615-1628.

(5) Taniguchi, T., Moriwaki, K., Automatic Mesh Generation for 3-D FEM, (2006), Morikita.

(6) Yamana, M., Ohta, T., Iwamoto, Y., Ogawa, N., Ishii, K., Ushio, M., Nakacho, K., Development of New Measuring Method of 3-Dimensional Residual Stress and Crack Propagation Simulation Method for Complex Welding Structure, Innovative and Viable Nuclear Energy Technology (IVNET) Development Report, (2004), The Institute of Applied Energy.

(7) Yamana, M., Ohta, T., Iwamoto, Y., Ogawa, N., Ishii, K., Ushio, M., Nakacho, K., Development of New Measuring Method of 3-Dimensional Residual Stress and Crack Propagation Simulation Method for Complex Welding Structure, Innovative and Viable Nuclear Energy Technology (IVNET) Development Report, (2005), The Institute of Applied Energy.

(8) Nikishkov, G.P., Atluri, S.N., Calculation of Fracture Mechanics Parameters for an Arbitrary Three-Dimensional Crack, by the 'Equivalent Domain Integral' Method, Int. J. Numer. Meth. Engng., Vol. 24 (1987), pp. 1801-1821.

(9) Shivakumar, K.N., Tan. P.W., Newman, Jr., J.C., A Virtual Crack-Closure Technique for Calculating
Stress Intensity Factors for Cracked Three Dimensional Bodies, Int. J. Fracture, Vol. 36 (1988), pp. R43-R50.

(10) MSC.Software Corporation, MSC.Marc Volume A-Theory and User Information Version 2003, (2003), MSC.Software Corporation.

(11) Okada, H., Araki, K., Kawai, H., Stress Intensity Factor Evaluation for Large Scale Finite Element Analysis (Virtual Crack Closure-Integral Method (VCCM) for Tetrahedral Finite Element), Transactions of the Japan Society of Mechanical Engineers, Series A, Vol. 73, No.728 (2007), pp. 498-505.

(12) Okada, H., Araki, K., Kawai, H., Stress Intensity Factor Evaluation for Large Scale Finite Element Analysis (Virtual Crack Closure-Integral Method (VCCM) for Mixed Mode / Complex Shaped Crack Using Tetrahedral Finite Element), Transactions of the Japan Society of Mechanical Engineers, Series A, Vol. 73, No.733 (2007), pp. 997-1004.

(13) Tokuda, T., Kawai, H., Okada, H., Fukui, Y., Development of Automated Crack Propagation Analysis System (1st Report, Outlines of the System and Finite Element Model Generation), Transactions of the Japan Society of Mechanical Engineers, Series $A$, Vol. 76, No. 770 (2010), pp. 1255-1262.

(14) Kawai, H., Okada, H., Araki, K.,A Mesh Generation Technique for ThreeDimentional Crack Propagation Analysis Using Virtual Crack Closure-Integral Method (VCCM) and Tetrahedral Finite Element, Transactions of the Japan Society of Mechanical Engineers, Series A, Vol. 74, No.742 (2008), pp. 819-826.

(15) ADVENTURE Project, "ADVENTURE", ADVENTURE Project, available from $<$ http://adventure.sys.t.u-tokyo.ac.jp/jp/>, (accessed 2010-4-1).

(16) Richard, H. A., Fulland, M., Buchholz, F. G, Schöllmann, M., 3D Fracture Criteria for Structures with Cracks, Steel Research, Vol. 74, (2003), pp. 491-497.

(17) Paris, P., Erdogan, F., A Critical Analysis of Crack Propagation Laws, J. Basic Engng., Vol. 85, (1963), pp. 528-534.

(18) Japan Society for Mechanical Engineers, Codes for Nuclear Power Generation Facilities -Rules on Fitness-for-Service for Nuclear Power Plants-, JSME S NA1-2004, (2004), p.E-2-4, Japan Society for Mechanical Engineers.

(19) Lazarus, V., Leblond, J.-B., Mouchrif, S.-E., Crack Front Rotation and Segmentation in Mixed Mode I+III or I+II+III. Part I: Calculation of Stress Intensity Factors, J. Mech. Phys. Solids, Vol. 49, (2001), pp. 1399-1420.

(20) Quan, J., Fatemi, A., Mixed Mode Fracture Crack Growth: A Literature Survey, Eng. Fract. Mech., Vol. 55, (1996), pp. 969-990.

(21) Newman, Jr. J.C., Raju, I.S., An Empirical Stress-Intensity Factor Equation for the Surface Crack, Eng. Fract. Mech., Vol. 15, (1981), pp. 185-192.

(22) $\mathrm{Si}, \mathrm{H} .$, Constrained Delaunay Tetrahedral Mesh Generation and Refinement, Finite Elements in Analysis and Design, Vol. 46 (2010), pp. 33-46. 